\title{
New finding sites of Drosophila suzukii (Matsumura, 1931) in perennial crops of Zagreb County
}

\author{
Nova nalazišta vrste Drosophila suzukii (Matsumura, 1931) \\ u višegodišnjim nasadima Zagrebačke županije
}

Ivana Pajač Živković, Dora Kapuđija

\begin{abstract}
The presence of invasive Drosophila suzukii (Matsumura, 1931) was investigated in three perennial crops (two orchards - Šurdovec and Donje Orešje and one vineyard Donje Orešje) in the area of Zagreb county. Samples of D. suzukii were collected during the three-month period (from August $18^{\text {th }}$ until November $18^{\text {th }}, 2017$ ) by using apple vinegar traps. The presence of $D$. suzukii was confirmed at all three investigated sites. In the orchard Šurdovec the lowest number (25 specimens) of D. suzukii was caught while the largest number (84 specimens) was caught in the orchard Donje Orešje. In all perennial crops $D$. suzukii was classified as eudominant species which implicates its invasive character. Sex ratio of D. suzukii at the orchard and vineyard Donje Orešje was female-biased while only in the orchard Šurdovec was male-biased which points to the further spread of the species in the area of Donje Orešje. The results of the research are a contribution to the knowledge of the distribution of this invasive species in the new areas of Zagreb County.
\end{abstract}

Key words: continental Croatia, eudominant species, invasive species, new records, perennial crops, spotted wing drosophila

\section{SAŽETAK}

Prisutnost invazivne vrste Drosophila suzukii (Matsumura, 1931.) istraživana je u tri višegodišnja nasada (dva voćnjaka - Šurdovec i Donje Orešje i jednom vinogradu - Donje Orešje) na području Zagrebačke županije. Uzorci D. suzukii skupljani su tijekom tromjesečnog razdoblja (od 18. kolovoza do 18. studenog 2017. godine) pomoću lovki na bazi jabučnog octa. Prisutnost $D$. suzukii potvrđena je na sva tri mjesta istraživanja. U voćnjaku Šrdovec utvrđen je najmanji broj (25 primjeraka) vrste $D$. suzukii, a najveći broj (84 primjerka) utvrđen je u voćnjaku Donje Orešje. U svim višegodišnjim nasadima vrsta $D$. suzukii klasificirana je kao eudominantna, što upućuje na njezin invazivni karakter. U voćnjaku i vinogradu Donje Orešje u populaciji vrste $D$. suzukii prevladavale su ženke, dok su u voćnjaku Šurdovec prevladavali mužjaci što upućuje na daljnje širenje vrste na području Donjeg Orešja. Rezultati istraživanja prilog su poznavanju rasprostranjenosti ove invazivne vrste na novim područjima Zagrebačke županije.

Ključne riječi: eudominantna vrsta, invazivna vrsta, kontinentalna Hrvatska, nova nalazišta, octena mušica ploda, višegodišnji nasadi 
Ivana Pajač Živković i sur.: New finding sites of Drosophila suzukii (Matsumura, 1931) in perennial crops of Zagreb County

\section{INTRODUCTION}

Spotted wing drosophila, Drosophila suzukii (Matsumura, 1931), is a major invasive pest of soft fruits in North and South America and Europe originating from South East Asia (Asplen et al., 2015). Wide host range, exceptional adaptability to different climatic conditions and high propagation potential supported its rapid spread and domestication to new areas (De Ros et al., 2015). After the first appearance in Europe and in the United States in 2008 (concurrent reports of the first finding in California (Walsh et al., 2011), Spain (Calabria et al., 2010) and Italy (Cini et al., 2012)), D. suzukii quickly colonized much of the United States and Canada as well as most European countries (Cini et al., 2014). Biological invasions are a leading threat to human and animal health, biodiversity and food production worldwide, and this polyphagous vinegar fly is threatening fruit production causing significant losses (Cini et al., 2014). In the United States the economic damage to fruit production of strawberry, raspberry, blueberry, blackberry and cherry was estimated at 500 million dollars every year (Bolda et al., 2010 cit. Cini et al., 2014), while the losses of the same fruits in European production (e. g. Italy) were estimated at 3.3 million euros per year (De Ros et al., 2013). In Croatia, the species was observed during 2010 on localities Škudelin and Petrovia in Istria County (Masten Milek et al., 2011) while first economic damages in the production of strawberries were observed in 2016 (Mešić et al., 2017). It is assumed that the species has been present in Croatia for some time, but it went unnoticed because it was misidentified for other vinegar flies such as Drosophila melanogaster Meigen, 1830 or Drosophila simulans Sturtevant, 1919 (Masten Milek et al., 2015).

Masten Milek et al. (2015) reported that in 2013 the presence of D. suzuki was confirmed in the following Counties: Sisak-Moslavina, Istria, PrimorjeGorski Kotar and Zadar.

Furthermore, the presence of pest was confirmed in cities Šibenik, Knin, as well as in Split Dalmatian and Dubrovnik Neretva County (Bjeliš et al., 2015; Masten Milek et al., 2015). During 2016 Pajač Živković et al. (2016) recorded its presence in vineyards of Donji Zebanec and Sveti Urban in Međimurje County.

Contrary to most other vinegar flies, D. suzukii lays eggs and feeds on undamaged ripening fruit of many plant species making infested fruit unmarketable (De Ros et al., 2015). Market zero tolerance to insect infestation of the fresh thin-skinned fruit is resulting in fruit growers having to make major efforts to control D. suzukii (Cuthbertson et al., 2014). 
Strategies to protect fruits from infestation by this insect are currently dominated by insecticide applications (e. g. organophosphate, pyrethroid and spinosyn) (Van Timmeren and Isaacs, 2013) which increases the price of fruit production worldwide and negatively affects people's health and the environment.

Although D. suzukii is widespread in Croatia (Bjeliš et al., 2015; Masten Milek et al., 2015) its presence in continental part of Croatia was poorly explored. Bjeliš et al. (2015) investigated its presence during the spring and summer season in orchards and individual host trees in Dalmatia region but similar investigations in orchards in the continental part of Croatia (e.g. Zagreb county) has never been carried out so far.

Timely observation of pests in fruit growing areas is of great importance in order to take timely protection measures. The aim of the study was to determine the presence and the number of individuals of D. suzukii in perineal crops in three localities within the Zagreb County.

\section{MATERIAL AND METHODS}

The study was conducted in the summer of 2017 on three localities (two orchards and one vineyard) in the area of Zagreb County. In the orchard

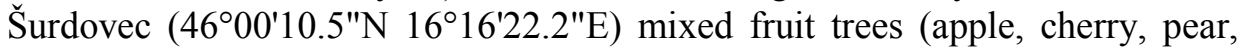
plum and apricot) are grown. At locality Donje Orešje two perennial crops (orchard and vineyard) are grown. In the orchard Donje Orešje $\left(45^{\circ} 59^{\prime} 47.5^{\prime \prime} \mathrm{N}\right.$ $\left.16^{\circ} 14^{\prime} 52.3^{\prime \prime E}\right)$ apples are grown, while in the vineyard Donje Orešje $\left(45^{\circ} 59^{\prime} 22.5^{\prime \prime} \mathrm{N} 16^{\circ} 14^{\prime} 36.0^{\prime \prime} \mathrm{E}\right)$ white wine grapes are cultivated.

This area is characterized by moderately warm-humid climate, with warm and rainy summers (Penzar and Penzar, 2000). According to data of the Croatian Meteorological and Hydrological Service (CMHS, 2018), August 2017 was warmer than the multi-year average (from 1961 to 1990) in the Republic of Croatia while the precipitation conditions for August 2017 were within average values.

Samples of $D$. suzukii were collected during the three-month period (from August $18^{\text {th }}$ until November $18^{\text {th }}, 2017$ ) by using apple vinegar traps. At each site one feeding trap was set up. For the determination of D. suzukii, the OEPP / EPPO diagnostic protocol PM 7/115 (1) (OEPP/EPPO, 2013) was used. The dominance of $D$. suzukii was calculated according to Tischler (1949) as follows: eudominant $(10-100 \%)$, dominant $(5-10 \%)$, subdominant $(2-5 \%)$, recedent $(1-2 \%)$ and subrecedent $(<1 \%)$. The $70 \%$ alcohol preserved flies are deposited 
in the Department for Agricultural Zoology, University of Zagreb, Faculty of Agriculture (Det. D. Kapuđija, leg. H. Virić Gašparić and I. Pajač Živković).

\section{RESULTS AND DISCUSSION}

During the monitoring period in 2017 the presence of D. suzukii was confirmed at all three investigated sites in Zagreb County. The highest number of vinegar flies (fam. Drosophilidae) was recorded in the orchard Surdovec (137), followed by the orchard Donje Orešje (94) while in the vineyard Donje Orešje the smallest number of drosophilid flies was recorded (39). In the orchard Surdovec the smallest number of D. suzukii specimens was caught while the largest number was caught in the orchard Donje Orešje.

In mixed fruit orchard Šurdovec 25 specimens of D. suzukii and 112 specimens of other drosophilids were detected. The species $D$. suzukii occupied $18.25 \%$ of the total catch, so it was classified as eudominant at this site (Figure 1).

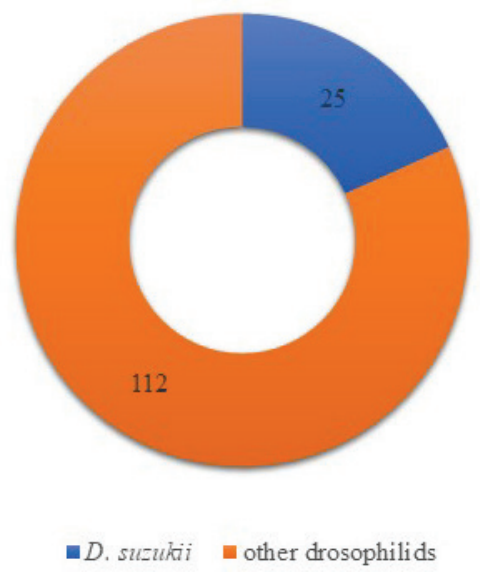

Figure 1 Total number of $D$. suzukii and other drosophilids in the orchard Šurdovec in 2017

Slika 1. Ukupan broj vrste D. suzukii i ostalih octenih muha u voćnjaku Šurdovec u 2017. godini.

In the apple orchard Donje Orešje, 84 specimens of D. suzukii and 10 specimens of other drosophilids were detected. Other vinegar flies occupied only $10.64 \%$ of the total catch, so with $89.37 \%$ species $D$. suzukii was classified as eudominant in the orchard Donje Orešje (Figure 2). 
Ivana Pajač Živković i sur.: New finding sites of Drosophila suzukii (Matsumura, 1931) in perennial crops of Zagreb County

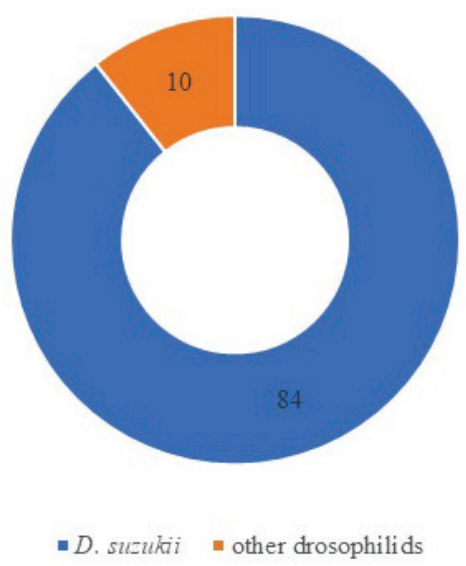

Figure 2 Total number of $D$. suzukii and other drosophilids in the orchard Donje Orešje in 2017

Slika 2. Ukupan broj vrste D. suzukii i ostalih octenih muha u voćnjaku Donje Orešje u 2017. godini.

In the vineyard Donje Orešje altogether, 28 specimens of D. suzukii and 11 specimens of other drosophilids were identified. Other drosophilids occupied only $28.21 \%$ of the total catch while D. suzukii occupied $71.79 \%$ and on this site was classified as eudominant (Figure 3).

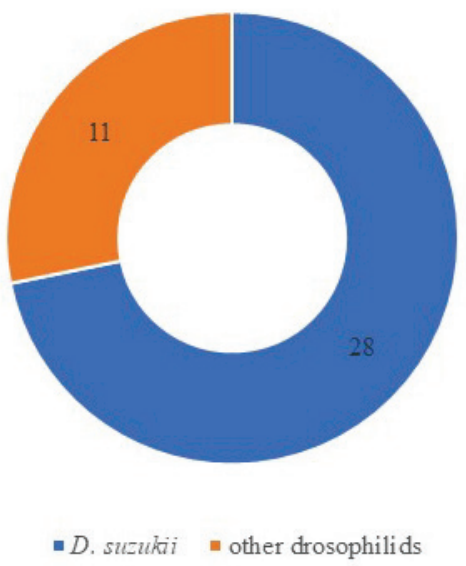

Figure 3 Total number of $D$. suzukii and other drosophilids in the vineyard Donje Orešje in 2017

Slika 3. Ukupan broj vrste D. suzukii i ostalih octenih muha u vinogradu Donje Orešje u 2017. godini. 
Sex ratio of $D$. suzukii at most investigated sites (orchard and vineyard Donje Orešje) was female-biased (> 50\%) while only in the orchard Šurdovec it was male-biased (60\%) (Table 1). These results indicate that at two out of the three study sites further expansion of $D$. suzukii population is expected because the natural sex ratio in insect population should be equal (Kovačević, 1959). If males dominate, further expansion of the population is threatened, but if females dominate, a population increase can be expected as it has a better biological potential (Pajač Živković et. al., 2019).

Table 1 Sex ratio of $D$. suzukii specimens collected in 2017 in perineal crops in Zagrebačka County

Tablica 1. Odnos spolova vrste D. suzukii prikupljene u 2017. godini u višegodišnjim nasadima Zagrebačke županije.

\begin{tabular}{|c|c|c|}
\hline \multirow{2}{*}{ Locality } & \multicolumn{2}{|c|}{ D. suzukii $(\%)$} \\
\hline & $\delta$ & q \\
\hline orchard Šurdovec & 60 & 40 \\
\hline orchard Donje Orešje & 42.86 & 57.14 \\
\hline vineyard Donje Orešje & 46.43 & 53.57 \\
\hline
\end{tabular}

The results of this study confirmed the presence of D. suzuki in orchards and vineyards in Zagreb County and since the species is well-spread in Croatia (Bjeliš et al., 2015 and Masten Milek et al., 2015) these data were expected. This pest is marked on the A2 list of quarantine pests in the EPPO region (EPPO, 2018) so determination of its presence and population abundance in new areas is of utmost importance. The dominance of $D$. suzuki was identified at all investigated sites and these results are in accordance with the first study of drosophilid fauna in the continental Croatia (Pajač Živković et al., 2016), which confirmed the dominance of D. suzuki in a Međimurje County vineyard (Donji Zebanec). The current faunistic research of pest population in Međimurje County (Pajač Živković et al., 2016) as well as these results are evidence of pest invasive character since only a few years after its first detection in 2010 (Masten Milek et al., 2011), it has become a dominant species in perennial crops at explored sites in continental Croatia. 
Ivana Pajač Živković i sur.: New finding sites of Drosophila suzukii (Matsumura, 1931) in perennial crops of Zagreb County

This research is contribution to the knowledge of D. suzukii distribution in Zagreb County and is proof of successful domestication of the species to a new area. In the future, similar investigations on its presence should be extended to the surrounding Counties in order to investigate the species dominance in perennial crops of wider geographic area since the sex ratio analyses showed further potential of the species spread. Timely detection of pest presence is a prerequisite for successful suppression and prevention of its spread, so this kind of research is of great importance.

\section{LITERATURE}

ASPlEN, M.K., ANFORA, G., BIONDI, A., CHOI, D.S., CHU, D., DAANE, K.M., GILBERT, P., GUTIERREZ, A.P., HOELMER, K.A., HUTCHISON, W.D., ISAACS, R., JIANG, Z., KÁRPATI, Z., KIMURA, M.T., PASCUAL, M., PHILIPS, C.R., PLANTAMP, C., PONTI, L., VÉTEK, G., VOGT, H., WALTON, V.M., YU, Y., ZAPPALÀ, L., DESNEUX, N. (2015): Invasion biology of spotted wing Drosophila (Drosophila suzukii): a global perspective and future priorities. Journal of Pest Science. 88(3): 469-494.

BJELIŠ, M., BULJUBAŠIĆ, I., POPOVIĆ, L., MASTEN MILEK, T. (2015): Spread of the spotted wing drosophila - Drosophila suzukii (Diptera: Drosophilidae) and new disitribution records in Dalmatia region of Croatia. Bulletin OEPP/EPPO Bulletin. 45(2): 214 - 217.

CALABRIA, G., MÁCA, J., BÄCHLI, G., SERRA, L., PASCUAL, M. (2010): First records of the potential pest species Drosophila suzukii (Diptera: Drosophilidae) in Europe. Journal of Applied Entomology. 136: 139 - 147.

CINI, A., IORIATTI, C., ANFORA, G. (2012): A review of the invasion of Drosophila suzukii in Europe and a draft research agenda for integrated pest managment. Bulletin of Insectology. 65(1): 149 - 160.

CINI, A., ANFORA, G., ESCUDERO-COOMAR, L.A., GRASSI, A., SANTOSUOSSO, U., SELJAK, G., PAPINI, A. (2014): Tracking the invasion of the alien fruit pest Drosophila suzukii in Europe. Journal of Pest Science. 87(4): 559-566.

CMHS (Croatian Meteorological and Hydrological Service) (2017): https://meteo.hr/klima_e.php?section=klima_pracenje\&param=klel\&Grad=za greb_maksimir\&Mjesec $=05 \&$ Godina $=2017$. Accessed on 14. 05. 2018. 
Ivana Pajač Živković i sur.: New finding sites of Drosophila suzukii (Matsumura, 1931) in perennial crops of Zagreb County

CUTHBERTSON, A.G.S., COLLINS, D.A., BLACKBURN, L.F., AUDSLEY, N., BELL, H.A. (2014): Preliminary Screening of Potential Control Products against Drosophila suzukii. Insects. 5: 488-498. doi:10.3390/insects5020488

DE ROS, G., ANFORA, G., GRASSI, A., IORIATTI, C. (2013): The potential economic impact of Drosophila suzukii on small fruits production in Trentino (Italy). IOBC-WPRS Bull. 91:317-321.

DE ROS, G., CONCI, S., PANTEZZI, T., SAVINI, L. (2015): The economic impact of invasive pest Drosophila suzukii on berry production in the Province of Trento, Italy. Journal of Berry Research. 5: 89 - 96.

EPPO (2018). EPPO A2 List of pests recommended for regulation as quarantine pests. https://www.eppo.int/QUARANTINE/listA2.htm. Accessed on 10. 04. 2019.

KOVAČEVIĆ, Ž. (1959): Primijenjena entomologija. Bd. 3. Anzeiger für Schädlingskunde 32(1), 13-13.

MASTEN MILEK, T., SELJAK, G., ŠIMALA, M., BJELIŠ, M. (2011): Prvi nalaz Drosophila suzukii (Matsumura, 1931.) (Diptera: Drosophilidae) u Hrvatskoj. Glasilo biljne zaštite. 11: 377 - 382.

MASTEN MILEK, T., ŠIMALA, M., BJELIŠ, M. (2015): Octena mušica ploda (Drosophila suzukii) - štetnik plodova voća. Glasilo biljne zaštite. 5/2015: $323-327$.

MEŠIĆ, A., PAJAČ ŽIVKOVIĆ, I., BARIĆ, B., DURALIJA, B. (2017): Prve ekonomske štete od novog štetnika voća (Drosophila suzukii). Zbornik sažetaka 12. znanstveno-stručnog savjetovanja hrvatskih voćara s međunarodnim sudjelovanjem: "Voćarstvo otočnog, obalnog i priobalnog područja". Vujević, P., Šimunović, V. and Čiček, D. (eds.) Zagreb: Hrvatska voćarska zajednica, 37-37.

OEPP/EPPO Diagnostics (2013): PM 7/115 (1): Drosophila suzukii. Bulletin OEPP/EPPO Bulletin. 43(3): 417 - 424.

PAJAČ ŽIVKOVIĆ, I., BARIĆ, B., LEMIĆ, D., BLAŽEVIĆ, I., ŠUBIĆ, M., SELJAK, G., MEŠIĆ, A. (2016): The Drosophilid Fauna (Diptera, Drosophilidae) of IPM Vineyards in Croatia. Agriculturae Conspectus Scientificus. 81(4): 231-234. 
PAJAČ ŽIVKOVIĆ, I., DURALIJA, B., BARIĆ, B., SELJAK, G., LEMIC, D., MEŚIĆ, A. (2019): The development of drosophilid species (Diptera, Drosophilidae) in different strawberry cultivars. Eur. J. Hortic. Sci. 84(1): 48-52.

PENZAR, I., PENZAR, B. (2000): Agrometeorologija. Školska knjiga, Zagreb.

TISCHLER, W. (1949): Grundzüge der terrestrischen Tierökologie. Braunschweig, Friedrich Vieweg und Sohn, Germany.

VAN TIMMEREN, S., ISAACS, R. (2013): Control of spotted wing drosophila, Drosophila suzukii, by specific insecticides and by conventional and organic crop protection programs. Crop Protection. 54: 126-133.

WALSH, D.B., BOLDA, M.P., GOODHUE, R.E., DREVES, A. J., LEE, J., BRUCK, D. J., WALTON, V.M., O'NEAL, S.D., ZALOM, F. G. (2011): Drosophila suzukii (Diptera: Drosophilidae): Invasive Pest of Ripening Soft Fruit Expanding its Geographic Range and Damage Potential. Journal of Integrated Pest Management. 2(1): 1-7.

\section{Adresa autora - Authors address:}

Ivana Pajač Živković, e-mail: ipajac@agr.hr

Dora Kapuđija, studij Fitomedicina

Agronomski fakultet Zagreb, Sveučilište u Zagrebu, Svetošimunska cesta 25, 10000 Zagreb 
Ivana Pajač Živković i sur.: New finding sites of Drosophila suzukii (Matsumura, 1931) in perennial crops of Zagreb County 